\title{
Urban Forced Eviction: Experiences in the Metropolitan City of Lagos, Nigeria
}

\author{
Ayobami Abayomi Popoola ${ }^{1}$, Michael Olaitan Olatunde ${ }^{2}$, Hangwelani Hope Magidimisha ${ }^{1}$, Abiodun \\ Amuda $^{2}$, Bamiji Michael Adeleye ${ }^{3}$, Lovemore Chipungu ${ }^{4}$
}

${ }^{1}$ Department of Town and Regional Planning, University of KwaZulu-Natal, South Africa. ${ }^{2}$ Department of Urban and Regional Planning, University of Ibadan, Oyo State, Nigeria. ${ }^{3}$ Department of Urban and Regional Planning, Federal University of Technology, Minna, Nigeria. ${ }^{4}$ Department of Housing, University of KwaZulu-Natal, South Africa.

Received: $2019-01-20$ Accepted: 2020-04-11

Key words:

Evictee, Eviction,;

Forced, Community;

Housing;

Development;

City,;

Lagos

Correspondent email: bcoolay2@yahoo.com

\begin{abstract}
Urban poverty coupled with housing shortages have contributed to the proliferation of informal settlements and slums. This is one of the complex problems arising out of urbanization and which is piling pressure on urban authorities to use unorthodox methods (such as forced evictions) to ameliorate the situation. This paper revisits the use of forced migration in Badia East Community of Lagos city. Using the human security concept as a framework for analysis, the paper chronicles how urban forced migration is used as a tool to relocate the vulnerable urban poor by urban authorities in their bid to achieve sustainable development. Critical insight into the nature of these migrations was achieved by gathering data using the mixed approach. Finding from the study revealed rampant human abuse through the use of force during the eviction process. The paper concludes by recommending that the government should use best practices, (such as adequate government-assistance) during relocations and rehousing option explored.
\end{abstract}

2020 by the authors Licensee Indonesinn Journal of Geography Indonesi.

This article is an open access article distributed under the terms and conditions of the Creative Commons

Attribution(CC BY NC) licensehttps://creativecommons.org/licenses/by-nc/4.0/.

\section{Introduction}

Forced eviction is a global phenomenon and a global crisis. Over 15 million people were reported to have been forcibly evicted during the 2000s (UN-Habitat, 2011), many of which occurred without prior notice, often with threats and the use of violence by the enforcer (Amnesty International, 2013). Forced eviction occurs in developing and developed countries alike in the context of development or emergencies and reconstruction (UNCHS, 1993; UNHabitat, 2003; Badiora, 2017). Unplanned and uncontrolled urbanization; city migration; housing demand and pressure; climatic induced disaster and shocks; globalization; financial; war; and other global crises have contributed to making forced evictions even more acute and complex (United Nation-UN, 2014; Dobson, 2017; Munoz, 2018).

Every year, millions of people around the world are forcibly evicted, leaving them homeless and in the process, entrenching patterns of discrimination and social exclusion (Sullivan, 2017; Keating, 2018). Studies by the Centre on Housing Rights and Eviction (COHRE) (2009) and Keating (2018) reported that poor and vulnerable communities are the most affected by common planning land ownership, which is often the basis for eviction. COHRE (2009) further states that vulnerable communities living on the edge of legality under informal tenure arrangements are the ones often evicted against their will, without consultation and compensation or alternative housing. Many evictions are counted not in thousands, but hundreds of thousands of people. Examples include the Rainbow Town evictions in Port Harcourt, Nigeria, in July 2000 which displaced 1,000,000 people; the New Delhi and Calcutta evictions in early 2004 which affected around 150,000 and 77,000 people respectively; and the 2008 Beijing evictions which affected an estimated 300,000 as a result of preparations for the Olympic Games (du Plessis, 2005).

These incidents are only a few of the many global instances where residents have been forcefully evicted from their homes by officials representing the constituted authority. The vulnerable and poor families in Nigeria always suffer the same fate. In July 1990, for example, over 300,000 residents were evicted from their homes in the Maroko area of Lagos State by Federal and State governments (Agbola and Jinadu, 1997). In April 2004, the Lagos State Task Force on 
the Environment demolished over 300 homes in Ogunbiyi village in Ikeja, leaving 3,000 people homeless; and in April 2005 , approximately 3,000 residents of the slum community of Makoko, Lagos were similarly forcibly evicted from their houses (Urban Poor Associates, 2006; Didymus, 2012; Ogunlesi, 2016). According to Srinivas (2004), Amnesty International (2006) and Habitat International Coalition (HIC) (2018), the Government of Nigeria is consistently one of the worst violators of housing rights in the world with over a million people forcibly evicted from their homes in different parts of the country over the past decade.

The forced eviction of the Badia East community of Lagos (on 23 February 2013) is among the worst evictions that occurred in Nigeria in recent years. This eviction was carried out by the staff of the Lagos State Physical Planning and Development Agency (LASPPDA) and others working for the Lagos State Environmental and Sanitation Task Force. Badia East is part of the broader Badia community, which is one of the nine settlements (slums) meant to benefit from the World Bank-funded Lagos Metropolitan Development and Governance Project (LMDGP). The objective of the US\$200 million project is to increase sustainable access to basic urban services through investments in critical infrastructure (World Bank, 2006). According to the LMDGP Project Appraisal Document, the infrastructure component of the project (estimated at US\$160.89 million) included upgrading drainage and solid waste facilities in nine of the largest slums identified in 1995 in Lagos State.

Part of the Badia community area cleared on February 23, 2013, has been earmarked for a housing development project by the Lagos State Ministry of Housing. According to the government, the project was not meant to benefit the evictees since the planned housing units were beyond their affordability. (Amnesty International, 2013). The housing project does not form part of the activities under the LMDGP, but the government has indicated that the location was chosen because the area had been earmarked for regeneration/renewal under the LMDGP. The national and local governments justified forced evictions on various reasons among which are the need to adhere to urban development plans (Ajanlekoko, 2001; Ocheje, 2007; Agbaje, 2013; Sullivan, 2017), the beautification of cities, privatization and cleaning up criminals from communities. Indeed it is not disputable that some of the buildings in question are unhealthy, unsafe and do serve as havens for criminals. Nevertheless, in the process, the vulnerable evictees are left with no alternative housing (Agbola and Jinadu, 1997; Sullivan, 2017; Marcus and Zuk, 2017; Nwobueze et al., 2018), resulting in the creation of a new informal settlements in other areas (Cernea, 1995; Alagbe, 2006). It is therefore not surprising that over $60 \%$ of the urban population in Nigeria resides in informal housing conditions (UN-Habitat, 2008; Fox, 2014).
The focus of this paper is on the Badia East community of Lagos in Nigeria. The overall aim is to establish the nexus between urban poverty and forced evictions by examining the physical and socio-economic impacts of forced evictions on residents of Badia East Community. More so, it questions the rationale for development-induced displacements by analyzing prevailing urban planning regulations that govern the built environment. To achieve this, the study hypothesizes that there is no significant relationship between forced evictions and urban poverty in the Badia East community of Lagos State.

\section{Rationale and Research Questions for the Study}

Even though adequate housing is a basic need and fundamental human right, it is still elusive for most urban dwellers in developing countries. In 2003, the UN Habitat estimated that a third of the world's urban population did not have access to adequate housing and its complementary facilities. The situation is aggravated by misplaced developmental drives that displace thousands of people (through evictions) who ironically, reside in informal settlements. Lagos, like other young metropolises in developing countries, experiences similar inconsistencies in urban development.

Authors (Ajanlekoko, 2001; Popoola et al., 2015) observed that the phenomenal rise in population, poverty, number, and size of cities over the past few years has manifested in the acute shortage of dwelling units which in turn resulted in overcrowding, high rentals, poor urban living conditions, low infrastructure services and increasing informal settlement development. Peculiar to Lagos State is the high urban population explosion, which has resulted in slum development (Nwanna, 2012) in places like the Badia community. After much neglect of the proliferating informal developments in Lagos State, the government is now increasingly using forced eviction as a tool to control the quality of life of the rich people at the expense of the urban poor (Gandy, 2005; Ocheje, 2007; Amakihe, 2017). To this end, this paper puts urban evictions in the spotlight by questioning the following: a) what is the livelihood and tenure security of the urban poor in Badia?; what are the pre- and posteviction experiences of the urban poor?; what is the manner and process in which eviction is carried out in the study area?; what is the effect of the eviction practice on the urban evicted in Badia?

\section{Human Security Concept: The Eviction and Evicted}

Unplanned and uncontrolled urbanisation in developing countries increases pressure on the urban footprint. The worst affected by such unconventional developments are the urban poor who are relegated to the urban periphery without any proper infrastructure and access to opportunities. This in turn indirectly aggravates urban poverty along the peripheries (Hossain, 2013) owing to the increasing cost of commut- 
ing to the city centre to access opportunities (Desmond and Shollenberger, 2015; Clarke et al., 2017). Paller (2017) noted that instances of urbanisation across African cities are on the increase. Emerging observations seem to show that the urban poor are among the key drivers of urbanization both spatially and demographically) as seen in the proliferation of slums and other forms of informal settlements. Poor urban management principles especially in managing such settlements in developing countries has resulted in labelling such areas as part of the "urban nuisances" which do not need any other remedial solution other than "removal". This is a radical approach to urban management which turns a blind eye to the human factor associated with the urban poor. The poor living conditions of these informal settlers are aggravated by lack of both human rights and property rights. In their article on poverty, urbanization and forced eviction, Islam and Mungai (2016), argued that poverty is both a cause and outcome of urban eviction of the poor. They further argued that in the face of capitalist urbanisation, the poor cannot afford facilities that prevail on the market (such as housing - thus resorting to informal settlements where they are constantly under the threat of urban management systems. Ensuing displacements do not only lead to the emergence of informal settlements, but they also increase the vulnerability of the urban poor.

The reported process of eviction in Nigeria has, over the years, left the evicted more vulnerable to poverty, death, and homelessness (COHRE, 2003; Amnesty International, 2006) and being undoubtedly insecure. Human security is an emerging paradigm for understanding global vulnerabilities. The proponents of this concept challenge the traditional notion of national security by asserting that the proper reference for security should be the individual who is evicted, rather than the state or private developer that engages in the eviction process (UNDP, 1994). Human security provides a people-centered, multi-disciplinary understanding of human security, fear of displacement, and vulnerability due to homelessness. Situating the human security concept in this study presents the views of the Commission on Human Security (CHS, 2003) which argues that human security is needed in response to the complexity and the interrelatedness of both old and new security threats (poverty, displacement, war), which tend to acquire transnational dimensions and move beyond traditional notions of security that focus on external military aggressions alone. CHS (2003) further iterates that a comprehensive approach that utilizes a wide range of new opportunities to tackle threats in an integrated manner is essential. Human security threats cannot be tackled through conventional mechanisms alone. Instead, they require a new consensus that acknowledges the linkages and the interdependencies between development, human rights, and national security.

While state security concentrates on threats directed against the state, usually in the form of military attacks, human security focuses attention on a broad scope of threats faced by individuals and communities. It focuses on the root causes of insecurities and advances people-centered solutions that are locally driven, comprehensive, and sustainable. As such, it involves a broader range of actors such as local communities, international organizations, civil society, as well as the state itself. Human security, however, is not intended to displace or replace state security. Instead, their relationship is complementary: human security and state security are mutually reinforcing and dependent on each other, such that the process of eviction is participatory, democratic and embraces the rule of law and the strengthening of the resilience of the people (evicted) and communities in a systematic manner, rather than a one-time clearance.

Thus, if all governments were to adopt this concept of human security rigorously, projects (especially development projects) would hardly leave impoverished victims in their wake. There would also be no feelings of hostility against authorities since the common top-down approach would be complemented with a people-centered bottom-up approach, thereby creating an enabling environment for participatory planning. At the very heart of this concept is participatory planning, a concept that helps to understand best practices, especially planning strategies that would benefit people, rather than further impoverish them.

\section{The Study Area: Profiling Lagos State and Badia East Community}

With a population of over 20 million people, a population density of 4,193 persons per sq. Km (Campbell, 2012) and a built-up land area of about 18,558 hectares (88.7\% metropolitan), Lagos is considered the most populous and second fastest-growing city in Nigeria and Africa (Filani, 2012; Citymayors.com, 2014).

Lagos State has 20 Local Government Areas (LGA), 16 of which make up the metropolis (located on latitudes $6^{\circ} 23^{\prime} \mathrm{N}$ and $6^{\circ} 41^{\prime} \mathrm{N}$ and longitudes $2^{\circ} 42^{\prime} \mathrm{E}$ and $\left.3^{\circ} 42^{\prime} \mathrm{E}\right)$. Apapa Local Government Area (LGA) is one of 16 metropolitan LGAs in Lagos State. Within Apapa LGA is Badia East community (latitude 30 23' and longitude 40 22') (Figure 1). The 2006 census states that Apapa Local Government Area has a population of 592,528 . Given the growth rate of $3.2 \%$, the Lagos Bureau of Statistics projected the population to be 700000 in 2018.

Badia East community is bounded in the north by LagosBadagry expressway, the National Theatre in the west, a railroad to Apapa in the east and Ajegunle (a low-income residential suburb) in the south. Before the displaced persons' arrival, Badia was already inhabited by the ancestral landowning Ojora chieftaincy family, their assignees and tenants. From the 1960s and through the late 1970s, Badia 


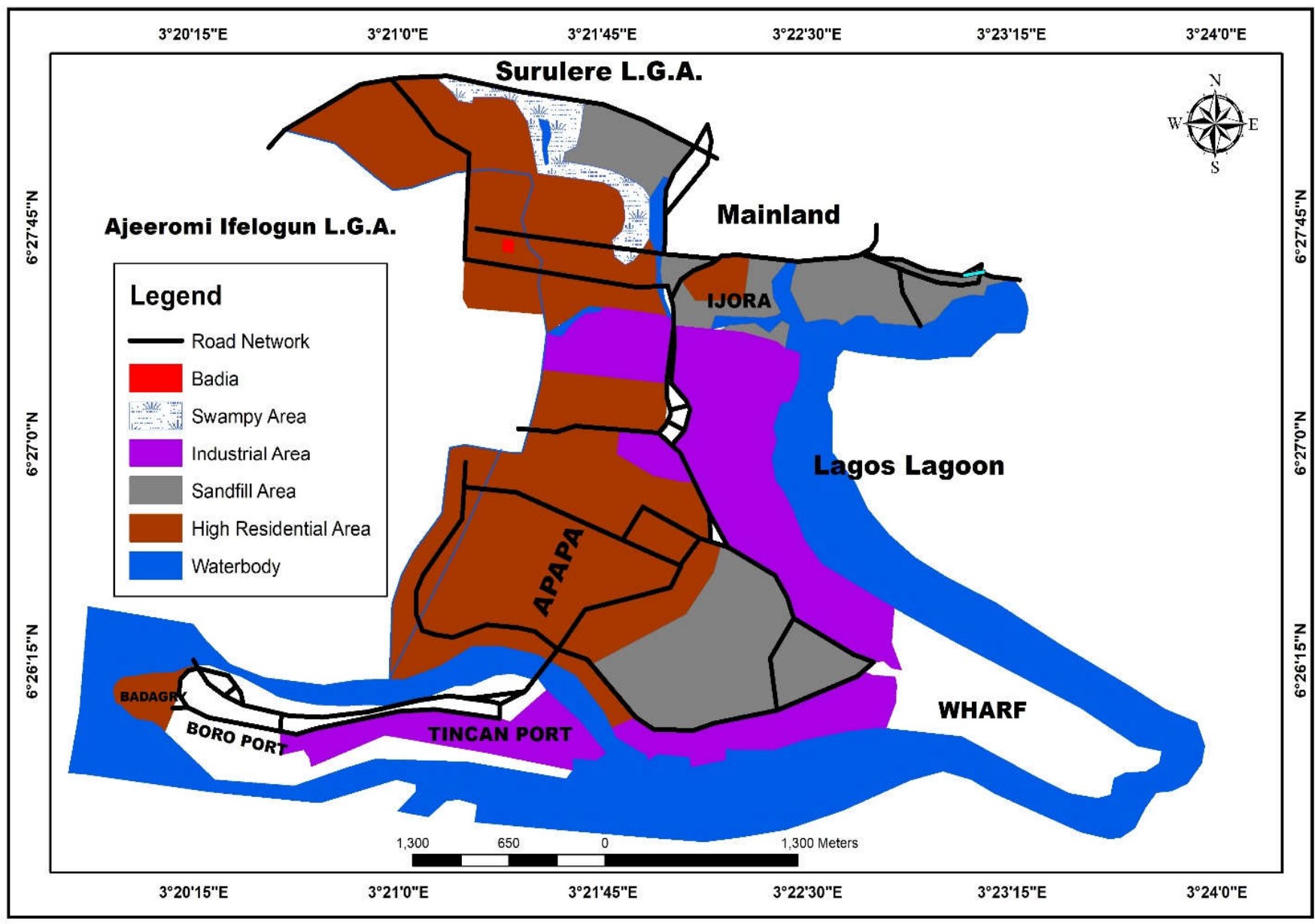

Figure 1. Apapa Local Government

Source: Authors' mapping, 2019

also become home to other populations displaced by development activities such as major road and bridge construction and industrial layouts. Due to its location and its history of British colonial and federal acquisition, the land of Badia East has, in recent decades, come under increasing pressure from competing ownership claims - thus fuelling the cycle of demolitions and forced evictions (Amnesty International, 2013).

In the 1990s, the Nigerian Railway Corporation claimed ownership based on the colonial acquisition of land from the traditional Ojora chieftaincy family dating back to 1929 and demanded rent from Badia East residents (Morka, 2007). Over the years, the population of Badia East has grown like the rest of Lagos State. From the original inhabitants who were mainly Ilaje, a Yoruba ethnic group, the population has diversified to include other ethnic groups in Nigeria such as Igbo, Hausa, Isoko and Urhobo groups, many of whom are poor and informal traders. The National Bureau of Statistics (NBS) (2010) has put the percentage of the poor in Lagos state at $70.24 \%$, and this class of people (many of whom are informal business traders) earn between 1 and 20,000 Naira (57.2USD at 350 Naira per US Dollar) monthly.

\section{The Methods}

The required data for this study was obtained from primary and secondary sources. Primary data was obtained through questionnaires, complemented with oral interviews with Community Leaders, Community Development Association (CDA) Chairmen, government agencies and parastatals, especially the Lagos State Physical Planning and Development Agency (LASPPDA). Secondary data is from sources such as maps, newspaper articles, documentaries, and publications from human rights organizations, Lagos State Physical Planning and Development Agency (LASPPDA) and COHRE.

The major source of primary data for this study is questionnaires that were administered to the affected persons (evictees), as well as officials of LASPPDA (evictor). The questionnaire administration on the evictees produced valuable information about the demographic and socioeconomic characteristics of residents of Badia over the last ten years, as well as what social and economic changes they have experienced as a result of evictions. The evictees were interviewed about their general standard of living since the displacement, notice of eviction and the eviction process. Information such as the purpose of the eviction, the legal confines within which these processes were carried out, as 

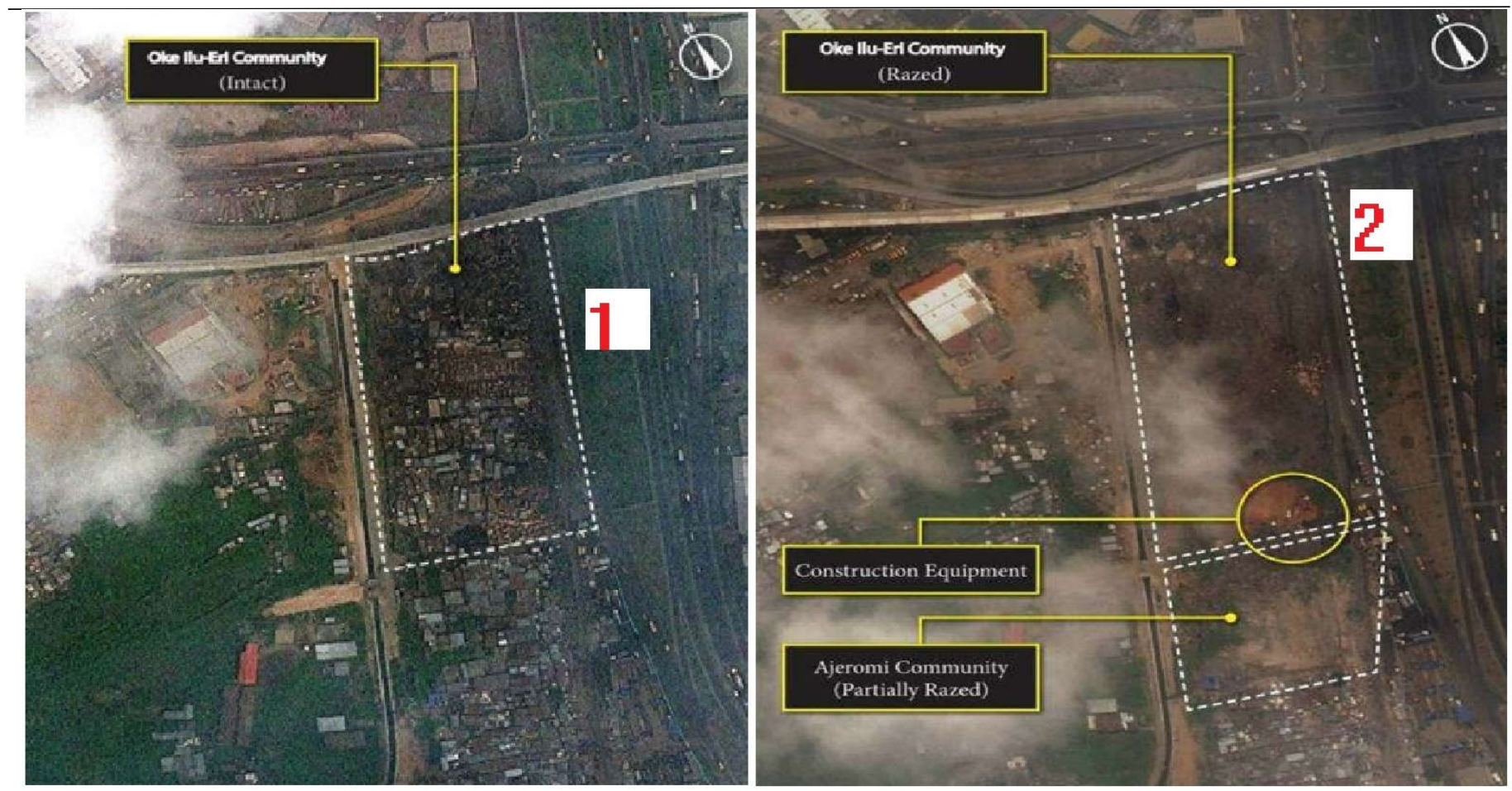

Figure 2. Pre and Post-Eviction Satellite Imagery of Badia East community, Lagos, Nigeria.

Source: Amnesty International, 2013.

well as whether there were plans for compensation and resettlement was obtained from the officials of LASPPDA.

\section{Sampling Procedure}

Owing to the type of study being undertaken, a purposive sampling method was deemed suitable since a particular group with common attributes is targeted (i.e., evictees). Furthermore, some of the evictees were not formally resettled and are scattered in various parts of the city. To locate these evictees, purposive sampling was employed in order to obtain key informants. These key informants included community heads and their representatives who proved to instrumental in supplying information about the whereabouts of some evictees. Subsequently, a snowball method was used to identify and select respondents. The snowball method involves eliciting information about other suitable respondents from a person who has just been interviewed. This is because non-probability approaches are more suitable for in-depth qualitative research in which the focus is often to understand complex social phenomena (Marshall 1996; Small, 2009). From literature, it has been identified that about 10,000 evictees have been displaced from their homes in the study area since the February 2013 eviction exercise (Amnesty International, 2013) (Figure 2).

The preliminary survey carried out on the study area, in addition to the information obtained from the news media indicates that a majority of evictees are still occupying makeshift shelters on the site. Thus, information about the current location of evictees was obtained through purposive sampling and the snowballing technique. The sample size was calculated using Yamane's (1967) formula. When this formula was applied to the speculated population of 10,000 evictees, the sample size arrived at is 384 respondents who were interviewed.

A comparative data analysis was carried out using the SPSS statistical software package. In analyzing the hypotheses, data collected from the field through questionnaire administration was subjected to Chi-square tests.

\section{Result and Discussions}

\section{Household Tenure of Evictees}

The predominant legal dwelling status in the community before the eviction was tenancy. From Table 1, it is clear that $68.6 \%$ of the respondents were tenants, while $31.4 \%$ were house owners. This was corroborated in discussions with some house owners who claimed to have had more than one building and accommodated several tenants before the eviction took place. From the sample, 19.5\% opined that for every five tenants, there are between three and four landlords. While $24.1 \%$ believed that there are almost as many Landlords as there are tenants, while $16.5 \%$ of the respondents believe that for every five tenants, there are two or three landlords.

Before the evictions, housing type varied, and so did rental values. Table 1 shows that out of the $68.6 \%$ respondents who were tenants, $77.4 \%$ of them stated that their annual rent was between $\$ 51,000$ and $\$ 70,000$, while $13 \%$ stated that they paid above $\$ 70,000$ annually. Only $9.6 \%$ of the tenants reported having paid between $\$ 31,000$ and \#50,000 annually as rentals before the evictions. The mean 
Table 1. Housing Tenure Characteristics of Evictees

\begin{tabular}{|c|c|c|c|c|c|c|}
\hline \multicolumn{3}{|c|}{ Legal Status of Respondents' Dwelling } & \multicolumn{4}{|c|}{ Percentage Ratio of Landlord to Tenant } \\
\hline Dwelling status & No. & $\%$ & Ratio of Landlords to Tenants & No. & & $\%$ \\
\hline Landlord & 95 & 31.4 & Below ratio $1: 5$ & & 0 & $\overline{0.0}$ \\
\hline Tenant & 208 & 68.6 & $1: 5-2: 5$ & & 26 & 8.6 \\
\hline Squatter & 0 & 0 & $2: 5-3: 5$ & & 50 & 16.5 \\
\hline \multirow[t]{2}{*}{ Total } & 303 & 100.0 & $3: 5-4: 5$ & & 59 & 19.5 \\
\hline & & & Above 4:5 & & 73 & 24.1 \\
\hline \multicolumn{3}{|c|}{ Housing Rent before Eviction } & Total & & 208 & 100.0 \\
\hline Annual Rent (N) & No. & $\%$ & & & & \\
\hline Less than 30000 & 0 & 0.0 & \multicolumn{4}{|c|}{ History of stay at Badia East Community } \\
\hline $31,000-50000$ & 20 & 9.6 & Length of stay in Badia & Frequency & & $\%$ \\
\hline $51000-70000$ & 161 & 77.4 & Less than 1 year & 14 & & 4.6 \\
\hline Above 70000 & 27 & 13.0 & $1-5$ years & 35 & & 11.6 \\
\hline \multirow[t]{3}{*}{ Total } & 208 & 100.0 & $5-10$ & 117 & & 38.6 \\
\hline & & & Above 10 years & 137 & & 45.2 \\
\hline & & & Total & 303 & & 100.0 \\
\hline
\end{tabular}

Source : Authors' primary data processing

rent paid by tenants before the eviction was said to be N5,000 per month for a room in a tenement building, which amounts to $\$ 60,000$ per annum. According to Numbeo (2015), the average cost of renting a one-room apartment in the city centre is $\$ 155,523.12$ per month, while the same apartment ( 1 bedroom) outside the city centre is $\$ 29,359.60$ per month. This would put the average rent of a onebedroom apartment outside the city centre at $\$ 360,000$ per annum. Further surveys on real estate agencies yielded that single room apartments cost between $\$ 250,000$ and \#300,000 per annum in the mainland. Thus, when juxtaposed with the average rent of well-equipped housing units, the rental values in Badia East community are quite low.

The majority of the respondents interviewed spent over a decade in Badia East. From the survey carried out, it was observed that $45.2 \%$ of the respondents had lived in Badia East community for over ten years. Table 1 shows that $38.6 \%$ of the respondents had spent between 5 and 10 years in the community, while $11.6 \%$ had spent between 1 and 5 years residing there. Fourteen respondents, representing $4.6 \%$ of the evictees sampled, had lived in Badia East for less than a year. This suggests that close to half of the evictees had already built their lives and had fully settled in the community, some claiming to have spent as much as over 40 years there. This also shows that Badia East is an enduring old community.

\section{Post-Eviction Analysis of Badia East Evictees:}

\section{Households, Housing, Neighbourhood and Social} Amenities

Just like a climate-driven disaster, forced evictions often trigger a post-effect shock or struggle amongst evictees individually. As for households, these shocks and threats to livelihoods have varying effects on pre- and post eviction experiences of the respondents. 'Before eviction' in this study refers to respondents' experiences in Badia community, while 'after eviction' refers to the evictees' experiences during and after the eviction process to another location from Badia. With regards to their livelihoods (as shown in Table 2 ), trading was their mainstay both before and after the evictions. Before the evictions, $74.3 \%$ of the respondents were traders who engaged in ventures such as food and foodstuff vending, selling lottery tickets, dealing in secondhand clothing, running GSM call centres, brothels, and beer parlors, amongst many others. Only $10.6 \%$ of the respondents were civil servants, and that remained the same after the evictions, while $11.2 \%$ were artisans who specialized in areas such as generator repairs, masonry, carpentry, and tailoring. However, after the evictions, the percentage of artisans dropped to 5.6\%. Moreover, before the evictions, $4.1 \%$ of the population interviewed claimed not to have had any employment, while the percentage increased to $14.8 \%$ as at the time of the interview.

Table 2 reveals that $49.8 \%$ of the respondents earned between $\$ 30,000$ and $\$ 50,000$ monthly before the eviction, 
Table 2. Perceptions on the Effects of Eviction on Individuals

Perception of changes in occupation owing to eviction

\begin{tabular}{lccccc}
\hline & Before Eviction & \multicolumn{3}{c}{ After Eviction } \\
\hline Occupation & Frequency & $\%$ & Frequency & $\%$ & \% Difference \\
\hline Civil Servant & 32 & 10.6 & 32 & 10.6 & 0.0 \\
Trader & 225 & 74.3 & 209 & 69.0 & -7.1 \\
Artisan & 34 & 11.2 & 17 & 5.6 & -50.0 \\
Unemployed & 12 & 4.1 & 45 & 14.8 & 260.9 \\
Total & 303 & 100.0 & 303 & 100.0 & \\
\hline
\end{tabular}

\begin{tabular}{|c|c|c|c|c|c|c|}
\hline \multicolumn{7}{|c|}{ Perceived effect of Eviction of Income } \\
\hline \multirow[t]{2}{*}{ Average monthly income (A) } & \multicolumn{3}{|c|}{ Before Eviction } & \multicolumn{2}{|c|}{ After Eviction } & \multirow[b]{2}{*}{$\%$ Difference $^{\star}$} \\
\hline & & Frequency & $\%$ & Frequency & $\%$ & \\
\hline $10,000-15,000$ & \multicolumn{2}{|r|}{0} & 0.0 & 160 & 52.8 & Infinity \\
\hline $15,000-20,000$ & \multicolumn{2}{|r|}{11} & 3.6 & 68 & 22.4 & 522.2 \\
\hline $20,000-30,000$ & \multicolumn{2}{|r|}{0} & 0.0 & 24 & 7.9 & Infinity \\
\hline $30,000-50,000$ & \multicolumn{2}{|r|}{151} & 49.8 & 51 & 16.8 & -66.3 \\
\hline Above 50,000 & \multicolumn{2}{|r|}{141} & 46.5 & 0 & 0.0 & Infinity \\
\hline Total & \multicolumn{2}{|r|}{303} & 100 & 303 & 100 & \\
\hline \multicolumn{7}{|c|}{ Daily Expenditure Changes owing to Eviction } \\
\hline \multirow[t]{2}{*}{ Daily Expenditure ( $\mathrm{N})$} & \multicolumn{2}{|c|}{ Before Eviction } & \multicolumn{3}{|c|}{ After Eviction } & \\
\hline & Frequency & $\%$ & Frequency & & $\%$ & $\%$ Difference $^{*}$ \\
\hline Less than 150 & 0 & 0.0 & 27 & & 8.9 & Infinity \\
\hline $150-300$ & 6 & 2.0 & 128 & & 42.2 & 2010.0 \\
\hline $300-500$ & 88 & 29.0 & 64 & & 21.1 & -27.3 \\
\hline Above 500 & 209 & 69.0 & 84 & & 27.7 & -59.8 \\
\hline Total & 303 & 100 & 303 & & 100 & \\
\hline
\end{tabular}

${ }^{\star}$ Negative sign signifies that the difference is a decrease

while $46.5 \%$ earned above $\$ 50,000$ during that same period. From the data obtained after the evictions, $52.8 \%$ of the respondents earned between 10,000 and 15,000 Naira as a monthly income, while $22.4 \%$ earned between 15,000 and 20,000 Naira during the same period. Only $16.8 \%$ of the interviewees claimed to earn between $\$ 30,000$ and $\$ 50,000$ monthly after the eviction. The result shows that no respondent earned between $\$ 10,000$ and $\$ 15,000$ before the evictions, while conversely, no respondent earned above 50,000 Naira monthly after the evictions.

It was further revealed that daily expenditure has been reduced among respondents since the eviction. The majority of respondents (69\%) claimed that they used to spend above 500 Naira daily before the eviction, while $29 \%$ claimed that they used to spend between 300 and 500 Naira daily (see Table 2). After the evictions, however, data obtained showed that $42.2 \%$ of the evictees currently spend between 150 and 300 Naira, and $21.1 \%$ of them spend between 300 and 500 Naira, while $27.7 \%$ now spend above 500 Naira. This can be linked to the decline in income, as shown in Table 2. Although this study did not investigate what accounted for the drop in average income after the eviction, an evictee has this to attest as to the reason for her drop in income:

"...I am a food seller, and my main customers are school children, early morning and late-night workers... ever since we (household) were chased from our former area (Badia East community), I rarely and even barely make half of my daily income, as in my new neighbourhood, there are existing and well-known food sellers... Owing to this, my daughter and I have resulted in food hawking to make up for our household income..." Badia East Community Evictee 
Table 3. Respondents' Access to Neighbourhood Facilities before and after the Eviction

\begin{tabular}{|c|c|c|c|c|c|}
\hline \multirow[b]{2}{*}{ School } & \multicolumn{2}{|c|}{ Before Eviction } & \multicolumn{2}{|c|}{ After Eviction } & \multirow[b]{2}{*}{ \% Difference } \\
\hline & Frequency & $\begin{array}{c}\text { Percentage } \\
(\%)\end{array}$ & Frequency & $\begin{array}{c}\text { Percentage } \\
(\%)\end{array}$ & \\
\hline Poor & 28 & 9.2 & 160 & 52.8 & 473.9 \\
\hline Fair & 222 & 73.3 & 126 & 41.6 & -43.3 \\
\hline Good & 53 & 17.5 & 17 & 5.6 & -68.0 \\
\hline Total & 303 & 100 & 303 & 100 & \\
\hline \multicolumn{6}{|c|}{ Health Centre } \\
\hline None & 7 & 2.3 & 17 & 5.6 & 143.5 \\
\hline Poor & 24 & 7.9 & 190 & 62.7 & 693.7 \\
\hline Fair & 238 & 78.5 & 79 & 26.1 & -66.8 \\
\hline Good & 34 & 11.2 & 17 & 5.6 & -50.0 \\
\hline Total & 303 & 100 & 303 & 100 & \\
\hline \multicolumn{6}{|c|}{ Place of Worship } \\
\hline None & 18 & 5.9 & 17 & 5.6 & -5.1 \\
\hline Poor & 78 & 25.7 & 193 & 63.7 & 147.9 \\
\hline Fair & 152 & 25.7 & 76 & 25.1 & -2.3 \\
\hline Good & 55 & 18.2 & 17 & 5.6 & -69.2 \\
\hline Total & 303 & 100 & 303 & 100 & \\
\hline \multicolumn{6}{|c|}{ Recreation Centre } \\
\hline None & 200 & 66.0 & 220 & 72.6 & 9.9 \\
\hline Poor & 61 & 20.1 & 48 & 15.8 & -21.4 \\
\hline Fair & 37 & 12.2 & 30 & 9.9 & -18.9 \\
\hline Good & 5 & 1.7 & 5 & 1.7 & 0.0 \\
\hline Total & 303 & 100 & 303 & 100 & \\
\hline \multicolumn{6}{|c|}{ Drainage Centre } \\
\hline None & 103 & 34.0 & 183 & 60.4 & 77.7 \\
\hline Poor & 86 & 28.4 & 80 & 36.4 & 28.2 \\
\hline Fair & 103 & 34.0 & 35 & 11.6 & -65.9 \\
\hline Good & 11 & 3.6 & 5 & 1.7 & -52.7 \\
\hline Total & 303 & 100 & 303 & 100 & \\
\hline
\end{tabular}

Source : Authors' primary data processing

This assertion by an evictee aligns with the views of Desmond and Gershenson (2017), who reported that there exists a relationship between eviction and the loss of a job. They argue that poverty of the household (which is often a reflection of the household), job loss, and family size are traits that mark urban eviction. Lancione (2017) also iterates that occupation displacement, coupled with weak household and individual capacity, often limit the survival and response of households to the shock of eviction. This is how one evictee responded job loss and daily expenditure:

"...Wae (meaning where is) the money to spend anyhow, person wae (that) lost hin (his) job dey (they) spend the small on them (people) dash am or hin hustle for anyhow..." Badia East Community

\section{Evictee}

Meaning, "where is the money to spend anyhow, can a person that lost his job (owing to eviction) spend the small money a friend gave him or work hard than the usual to get anyhow." This statement explains the issue of income limita- tion, which indirectly influences individual expenditure. Marcus and Zuk (2017) further aver that poverty limits the choice of housing when eviction is at hand. Their study respondents in San Mateo, California, reported that limited income and weak purchasing power often give landlords the right to harass tenants, price them out of the market and also push them into more impoverished housing conditions.

Respondents' Access to Neighbourhood Facilities before and after the Eviction

From the study, urban evictees in Badia community widely expressed the sentiment that the community school was fair. Table 3 shows that $73 \%$ of the respondents had access to fair schooling services, while $52.8 \%$ now have access to inadequate schooling facilities. In contrast with the most satisfactory level of schooling facilities experienced by the respondents before the eviction, only $41.2 \%$ still have access to fair schooling services. The limitation of access according to field observation reveals that costs of utilization or access (in the form of school uniforms, purchase of books, 


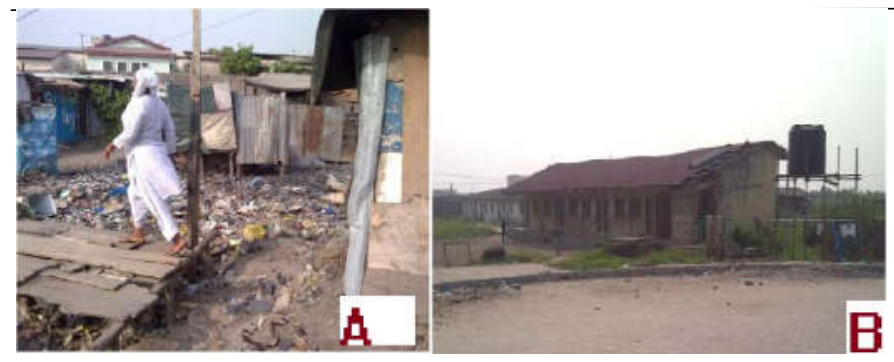

Figure 3. Wooden Platform over Stagnant Water owing to Lack of Drainage (A) and The Government Secondary school in the area (B)

Source: Authors' Survey

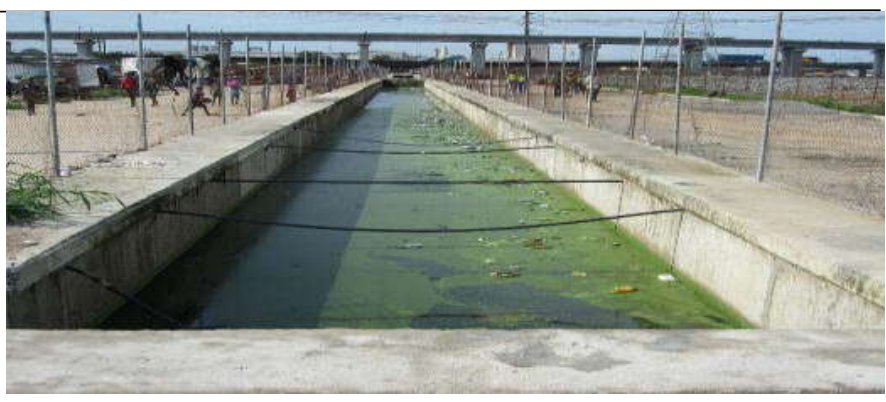

Figure 4. Canal constructed as part of the LMDGP Source: Amnesty International, 2013.

Table 4. Availability of Basic Amenities before and after Evictions

\begin{tabular}{|c|c|c|c|c|c|}
\hline \multirow{2}{*}{$\begin{array}{l}\text { Facility Type } \\
\text { Electricity }\end{array}$} & \multicolumn{2}{|c|}{ Before the Eviction } & \multicolumn{2}{|c|}{ After the Eviction } & \multirow[b]{2}{*}{ \% Difference } \\
\hline & Frequency & $\%$ & Frequency & $\%$ & \\
\hline None & 65 & 21.5 & 121 & 39.9 & 85.6 \\
\hline Poor & 134 & 44.2 & 155 & 51.2 & 15.9 \\
\hline Fair & 87 & 28.7 & 22 & 7.3 & -74.6 \\
\hline Good & 17 & 5.6 & 5 & 1.7 & -69.6 \\
\hline Total & 303 & 100.0 & 303 & 100.0 & \\
\hline \multicolumn{6}{|l|}{ Road } \\
\hline None & 48 & 15.8 & 153 & 50.5 & 219.6 \\
\hline Poor & 215 & 71.0 & 128 & 42.2 & -40.6 \\
\hline Fair & 35 & 11.6 & 17 & 5.6 & -51.7 \\
\hline Good & 5 & 1.7 & 5 & 1.7 & 0.0 \\
\hline Total & 303 & 100.0 & 303 & 100.0 & \\
\hline \multicolumn{6}{|l|}{ Security } \\
\hline None & 108 & 35.6 & 114 & 37.6 & 5.6 \\
\hline Poor & 142 & 46.9 & 151 & 49.8 & 6.2 \\
\hline Fair & 43 & 14.2 & 28 & 9.2 & -35.2 \\
\hline Good & 10 & 3.3 & 10 & 3.3 & 0.0 \\
\hline Total & 303 & 100.0 & 303 & 100.0 & \\
\hline \multicolumn{6}{|l|}{ Refuse Disposal } \\
\hline None & 211 & 69.6 & 243 & 80.2 & 15.2 \\
\hline Poor & 57 & 18.8 & 25 & 8.3 & -55.9 \\
\hline Fair & 30 & 9.9 & 30 & 9.9 & 0.0 \\
\hline Good & 5 & 1.7 & 5 & 1.7 & 0.0 \\
\hline Total & 303 & 100.0 & 303 & 100.0 & \\
\hline
\end{tabular}

and school levies) to the education facility remain a limitation to poor urban households. It was also observed that increasing revenue demands on households result in informal trading activities and a search for unskilled jobs by younger children across households, instead of going to school.
From this data, it is apparent that the quality of schooling amongst households has been affected either by relocation from eviction or the cost of access. Regarding access to health services, $78.5 \%$ of the respondents confirmed access to a fair health centre before the eviction, while $63.7 \%$ lamented access to inadequate health facilities. Furthermore, the data retrieved, as presented in Table 3, shows that recreational 
Table 5. Availability and Quality of Prior Notification of the Eviction

\begin{tabular}{|c|c|c|c|c|}
\hline \multirow[b]{2}{*}{ Questions Asked } & \multicolumn{2}{|c|}{ Yes response } & \multicolumn{2}{|c|}{ No response } \\
\hline & Respondents & $\%$ & Respondents & $\%$ \\
\hline Did you receive prior notification? & 7 & 2.3 & 296 & 97.7 \\
\hline Did the notification contain justification? & 7 & 2.3 & 296 & 97.7 \\
\hline Did the notification contain an explanation? & 0 & 0.0 & 303 & 100.0 \\
\hline Did the notification contain info on relocation? & 0 & 0.0 & 303 & 100.0 \\
\hline Did the notification contain info on compensation? & 0 & 0.0 & 303 & 100.0 \\
\hline Did the notification contain info on legal recourse? & 0 & 0.0 & 303 & 100.0 \\
\hline Was there opportunity to object to the eviction? & 6 & 2.0 & 297 & 98.0 \\
\hline
\end{tabular}

Source : Authors' primary data processing

facilities were lacking before the evictions, and the respondents still do not have adequate access to such after being evicted. A majority (66\%) of respondents replied that they had no access to recreational facilities before the eviction, while $72.6 \%$ have no access after the eviction.

Drainage facilities are currently inadequate, a fact which was discerned during the survey carried out on the site. However, $34 \%$ of the respondents claimed that they had no drainage facilities at all in the area before the eviction, and another $34 \%$ claimed that there were drainage facilities in fair condition before the eviction. The analysis shows that $60.4 \%$ of the evictees currently have no access to drainage facilities (as represented in Figure 3), while 36.4\% and 11.6\% have access to poor and fair drainage facilities, respectively.

The only structure bearing the semblance of a drainage facility was the Canal, which Badia East community benefited through the Lagos Metropolitan Development and Governance Project (LMDGP), but was laden with debris, as seen in Figure 4.

The situation of basic amenities before and after the evictions

Basic amenities essential for convenient living in an environment mainly include electricity, roads, and waste disposal services (among others). The security of an environment ought to be adequately considered as well. Respondents were quizzed about the conditions of such amenities and the data obtained is presented in Table 5. It is clear (from Table 5) that access to electricity was limited in the community before the eviction. Some respondents from the field noted that there was no public supply (21.5) while others $(44.2 \%)$ simply said that supply was poor. Only $5.6 \%$ responded that supply was good before the eviction. After the evictions, $51.2 \%$ of the respondents currently have poor electricity supply where they are, and $39.9 \%$ have no supply at all. Responding to the condition of facilities, many of the respondents opined that the means of circulation on site were poor. Responding dwellers stated that motorcycles remain the best means of connecting temporary houses in the area. Field observation, however, confirmed a path of paved walkways stretching from the North of the site to the south and terminating abruptly at both ends. This is the only paved road surface in the area and is not motorable. Furthermore, from the data collected, it is seen that $50.5 \%$ of the respondents have no good roads in their current places of abode.

Concerning security, $35.6 \%$ of the respondents believed that the area as it was before the evictions lacked adequate security, while $46.9 \%$ opined that security was poor before the evictions. Only $14.2 \%$ rated security as fair, while $3.3 \%$ affirmed that security could be rated as 'good' before the evictions. After the evictions, $49.8 \%$ of the respondents believe that their current place of abode lacks security; $69.6 \%$ of the respondents had no means of waste or refuse disposal before the evictions, while $18.8 \%$ feel that there were waste disposal methods despite being crude or poor. Credence is given to these responses by the ubiquitous pockets of refuse around the area. However, $80.2 \%$ of respondents believe that their current area has no waste disposal methods at all, making it worse than their former area in terms of refuse disposal.

\section{The Eviction Process in Badia East Community}

This study queried the process of evictions during data collection process. Questions were asked to examine if ethical issues such as the serving of notification, use of force or violence, and provision for relocation, amongst others, were experienced by evictees. Best practice in evictions stipulates that the authorities should inform the targeted population beforehand. In the Nigerian context, the relevant Authorities ought to fulfill the following according to Section 84 (1) of the Nigerian Urban and Regional Planning Law No 88 of 1992:

1. Affix a notice of the proposed order onto a conspicuous part of the building to which the order relates;

2. Appoint a committee of members of the authority to hear, consider and report on any representation or objection which may be made orally and in writing 
Table 6. Compliance with Best Practice during the Conduct of Evictions

\begin{tabular}{ccccccc}
\hline & \multicolumn{2}{c}{ Violence } & \multicolumn{2}{c}{$\begin{array}{l}\text { Loss of person- } \\
\text { al belongings }\end{array}$} & \multicolumn{2}{c}{ Provision for relo- } \\
& & & \multicolumn{2}{c}{ cation } \\
& Fre- & $\%$ & Fre- & $\%$ & Fre- & $\%$ \\
& quency & & quency & & quency & \\
\hline Yes & 236 & 77.9 & 179 & 59.1 & 0 & 0.0 \\
No & 67 & 22.1 & 124 & 40.9 & 303 & 100.0 \\
Total & 303 & 100 & 303 & 100 & 303 & 100 \\
\hline
\end{tabular}

Source : Authors' primary data processing
Figure 5. Shelters where some evictees now reside owing to the lack of provision for relocation

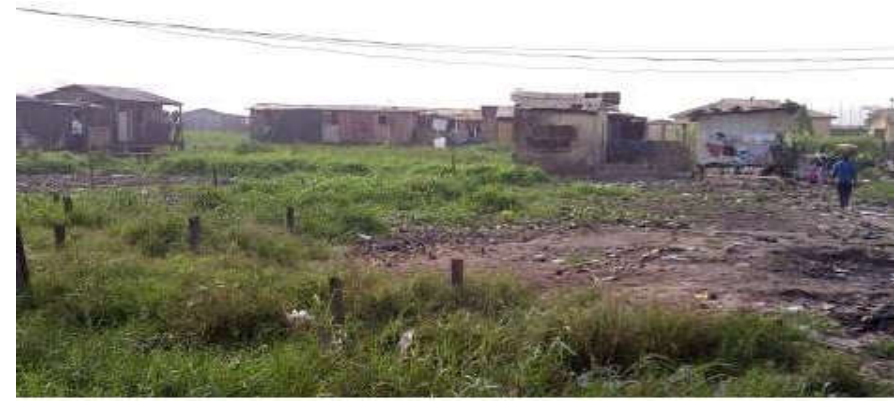

Source: Authors' Survey

Table 7. Cross-tabulation between Income before and after Evictions and Chi-Square test

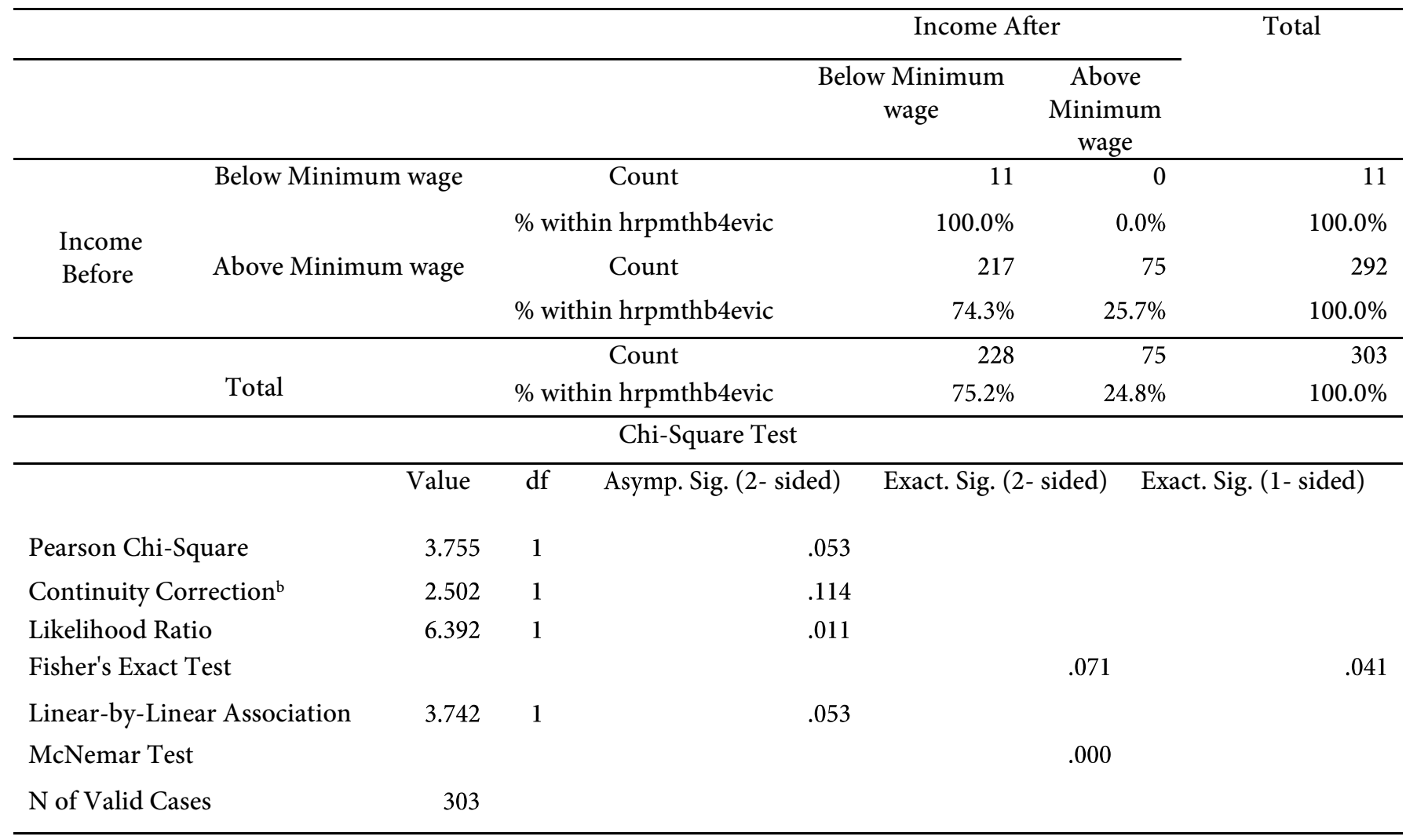

by the owner or occupier or his duly authorized representative;

3. Prepare an estimate of the compensation payable to the owner-occupier of the building, as well as information on relocation if available;

4. Explain as to why the eviction must occur; and

5. Outline steps for obtaining legal recourse.

Section (84) (4)(a \& b) of the Nigerian Urban and Regional Planning Law of 1992 also states that the order to demolish or evict residents from an area marked for improvement can only commence when there is no appeal against the order, at least 28 days after its service on the owner or occupier of the building or if there is an appeal against the order, at least 28 days after the appeal has been finally determined or dismissed.

The results from the survey presented in Table 5 show that the evictees were largely unaware of any notifications.
When asked whether they received prior notice, only 7 respondents (which represents $2.3 \%$ of those interviewed) replied that they were notified. These also claimed that the notification contained a justification for the demolitions, but did not contain information on compensation, relocation or legal recourse.

Evidence presented in Table 6 shows other pertinent issues that attract national and international interest in eviction cases. A significant number of respondents (77.9\%) affirmed the occurrence of violence during evictions, while $22.1 \%$ said that they did not witness any violence. Over half (59.1\%) of those interviewed also experienced loss of personal belonging such as money, electronic devices such as TV sets, refrigerators, fans, and mobile phones during evictions. Only $40.9 \%$ of respondents said that they did not experience loss of personal belongings. It is worth noting that all respondents confirmed that there was no provision 
Table 8. Cross-Tabulation between Daily Expenditure before and after the Evictions

Income After

Total

\begin{tabular}{|c|c|c|c|c|c|c|}
\hline & & & & Below Minimum wage & \multicolumn{2}{|l|}{$\begin{array}{l}\text { Above Minimum } \\
\text { wage }\end{array}$} \\
\hline & \multicolumn{2}{|c|}{ Below Minimum wage } & Count & 11 & 0 & 11 \\
\hline & & & $\%$ within hrpmthb4evic & $100.0 \%$ & $0.0 \%$ & $100.0 \%$ \\
\hline \multirow{3}{*}{$\begin{array}{l}\text { Income } \\
\text { Before }\end{array}$} & \multicolumn{2}{|c|}{ Above Minimum wage } & \multirow{2}{*}{$\begin{array}{l}\text { Count } \\
\text { \% within hrpmthb4evic }\end{array}$} & 217 & 75 & 292 \\
\hline & & & & $74.3 \%$ & $25.7 \%$ & $100.0 \%$ \\
\hline & & & Count & 228 & 75 & 303 \\
\hline \multicolumn{3}{|l|}{ Total } & \% within hrpmthb4evic & $75.2 \%$ & $24.8 \%$ & $100.0 \%$ \\
\hline \multicolumn{7}{|c|}{ Chi-Square Test } \\
\hline & & Value & Asymp. Sig. (2- si & \multicolumn{2}{|c|}{ Exact. Sig. (2- sided) } & (1- sided) \\
\hline \multicolumn{2}{|c|}{ Pearson Chi-Square } & 3.755 & 1 & .053 & & \\
\hline \multicolumn{2}{|c|}{ Continuity Correction ${ }^{\mathrm{b}}$} & 2.502 & 1 & .114 & & \\
\hline \multicolumn{2}{|c|}{ Likelihood Ratio } & 6.392 & 1 & .011 & & \\
\hline \multicolumn{3}{|c|}{ Fisher's Exact Test } & & & .071 & .041 \\
\hline \multirow{2}{*}{\multicolumn{2}{|c|}{$\begin{array}{l}\text { Linear-by-Linear Asso- } \\
\text { ciation } \\
\text { McNemar Test }\end{array}$}} & 3.742 & 1 & .053 & & \\
\hline & & & & & .000 & \\
\hline \multicolumn{2}{|c|}{$\mathrm{N}$ of Valid Cases } & 303 & & & & \\
\hline
\end{tabular}

Source : Authors' primary data processing

for relocation whatsoever made before, during, or after the eviction process. This explains why the majority of them still reside in makeshift dwellings around the eviction site or taking up refuge with friends at other informal settlements (Figure 5).

Adekola et al. (2017) emphasise that evictees are often subjected to health challenges, which can be physical, psychological or economic. They argue that cases of depression are common characteristics of evictees in Nigeria, as most of the process of eviction does not take into consideration the welfare of the people. To further explain the relationship between forced evictions and the poverty levels of evictees, the study hypothesis is that eviction has no effect on the income level and daily expenses of the evictees of Badia East Community. Statistical tests of a significant relationship were run on indicators of poverty (income and daily expenditure) as included in the study questions. The data obtained for these variables are categorical, and as such, statistical tests which suit categorical data would be most appropriate. For this, McNemar's Test was selected. The test is well suited to examine the difference between income and expenditure before and after evictions. This considers whether or not the eviction would result in diminished income. To carry out this test, a $2 \times 2$ contingency table was computed for wage levels, grouping the data into below minimum wage and above minimum wage (where minimum wage is $\$ 18,000 / 51.5 \mathrm{USD}$ ) before and after the evictions.
Then McNemar's test was run on the table. The outcome of the hypothesis test showed that eviction had no effect on the income levels of evictees in Badia East Community as shown in Table 7.

Evidence from field observation and interviews revealed that many of the evictees lost their jobs and the primary source of income, as many of them engaged in informal trading such as selling of food, trading, airtime vendors, phone and electronic technician, and waste collectors. One male evictee responded as follows to the issue of eviction and employment:

"I am old to work, but one of my children who was selling recharge cards and repair phones lost many of his customers when we (entire household of 4 occupants) had to leave (evicted). Now I see him trying to get his footing in the new location and also convince the new potential customers of his skill and expertise, especially phone repairs". Badia East Community Evictee

To determine whether the eviction could be responsible for a diminished daily expenditure or not, McNemar's test was carried out using a $2 \times 2$ contingency table using daily expenditure. This involved grouping the data into below $a$ dollar a day and above a dollar, a day (an exchange rate of 150 Naira to a dollar was used for this grouping) for before 
and after the evictions. The $150 / \mathrm{USD}$ was considered appropriate using the exchange rate prevailing at the time of the research. The test was based on the hypothesis that: Eviction has no effect on the daily expenditure of the evictees of Badia East Community. The results showed that the P-value for the McNemar's Test is 0.000 - as such, $\mathrm{P}<0.05$ - thus symbolizing that the hypothesis was rejected (see Table 8 ). Thus, the eviction affected the daily expenditure of the evictees. More evictees were living on a dollar a day and less after the evictions than before the evictions.

\section{Institutional Responses to the Survey on the Forced Eviction of Badia East Community Residents}

Further responses to pertinent issues relating to the conduct of evictions and the subsequent housing project were solicited from the supervising agencies and ministries responsible for the conduct of the evictions and the subsequent housing project. During the field survey, it was learnt that the State Ministry for Housing was the supervising Parastatal. In addition to the Ministry of Housing, significant stakeholders in the evictions included The Lagos State Ministry of Justice, Lagos State Lands' Bureau, Lagos State Ministry of Physical Planning and Urban Development, Lagos State Environmental and Special Offences Enforcement Unit, The World Bank Civil Rights' Organizations - Social and Economic Rights Action Center (SERAC) and Amnesty International. The questions revolve around matters such as pre-eviction modalities, the conduct of the evictions, and post-eviction modalities. The roles played, and duties performed by these institutions were adequately examined through interviews conducted, and responses to open-ended structured questionnaire.

\section{Consultations After the evictions}

According to the response obtained from the Ministry of Housing, the Government consulted with the evictees through its representatives. These evictees were exposed to a wide range of information such as handbills, posters and jingles in order to convince them to attend meetings on evictions. The purpose of the meetings was appraise evictees on how the decision on eviction was decided upon and the government's position on compensation. A feasibility study on the status of the evictees was undertaken by the government and it established that there were no anticipated short, medium or long-term effects of evictions on the livelihoods of the evictees. The government further set up a technical committee to redress grievances and to consult with evictees on the resettlement process.

However, many of the sentiments or views expressed by the Ministry of Housing as a supervising government organ on the project are not in line with those expressed by evictees. Some of these contradictions relate to the issuing of notifications prior to the eviction and assistance with reloca- tions. It is these inconsistencies and contradictions that attracted the attention of civil rights organization. Apart from materially supporting evictees, civil rights organisations also engaged in protracted legal battles with the government. One such legal issue was the preparation of a Resettlement Action Plan which was submitted to the Abuja office of the World Bank. This is just one of the many correspondences between the World Bank, SERAC, Amnesty International, and the Lagos State Government, whom the Ministry of Justice represents. These Civil Rights organizations opined that the entire process of the evictions was illegal, and as such, adequate compensation instead of 'minimal financial assistance' ought to be paid to the affected persons.

\section{Inadequate Compensation}

It is noteworthy to mention that the Stakeholders considered the payment given to evictees as 'financial assistance,' rather than compensation. Regarding the inadequacy of this payment, the World Bank maintained its position that prompt payment was made to over 9,000 evictees and considered this to be a good outcome, particularly in a context in which the evictees are considered illegal squatters under local law. The Panel (consisting of Lagos Metropolitan Development and Governance Project Board made up of World Bank and Lagos state government officials) went on to cite the provision of compensation to evictees by the Lagos State Government for an eviction caused by a project financed by them, establishment of structures and processes such as the Technical Committee to redress grievance as an important precedent with the possibility for a longer-term impact. It is also worth to note that the LMDGP was closed on September 30, 2013. The World Bank reiterated that the evictions did not take place as part of the project, and any effort to pursue a lengthy process of investigation would not yield improved outcomes for the evictees. Interestingly, however, the World Bank provided funding to the Lagos State Government as a loan for the 'financial assistance' paid to the evictees.

\section{Conclusion}

The primary cause of slum proliferation is lack of affordable housing options in large cities. Thus, migrants, as well as former evictees and their families, occupy private and public land without permission, which in turn exposes them to precarious living conditions and a constant risk of forced eviction. This is the vicious cycle in which the less privileged find themselves. Granted, public or private land is sometimes occupied without permission by people. However, in such instances, forced evictions are not the only option. Several sustainable initiatives can be sought to strengthen the security of tenure and increase access to adequate housing for urban dwellers, especially those who have occupied these 
properties for long periods and have set up livelihoods there over a period of time. These include programmes to upgrade and legalize informal settlements, land titling initiatives, legislative and policy reforms, and programmes to reform; and develop the capacity of land management institutions.

Although there have been a few positive examples in the provision of public housing in Lagos State, there is still more to be achieved in the realm of security of tenure in urban areas. Proper legislation and land and housing policies are essential to guarantee tenure security and urban development plans must take into account the needs and rights of the poor and the most vulnerable. These plans should aim to make life bearable for them at the very least, and not make them worse off.

Indeed, the problem of urban poverty cannot be adequately or successfully managed if authorities continue to fuel the symbolic embers responsible for it. This reflects a decline in the income and an increase in the expenditures of the evictees. The increasing expenditure puts in shock and stresses the livelihood conditions of the evictee, as shown in the tested hypothesis. Evidence reported shows that the eviction process ultimately affects the sources of job and infrastructure enjoyed by many of the respondents. It was reported that the need to re-plan and reconstruct new informal spaces ultimately affects the income base and expenditure of the urban poor. The human security evidence, as revealed from the study, presents a further increased vulnerability rather than an opening of opportunities as a result of the eviction process. There also cannot be any sustainable development if the authorities themselves are responsible for the creation of an enabling environment for poverty to foster. Government authorities in third-world countries, especially Nigeria, must adopt a more humane approach to developmental planning. Livelihoods ought not to be jeopardized for the sake of development since doing this is inherently counter-productive. These authorities must accept as their responsibilities in the provision of adequate housing for the masses that form the bulk of the population. Guidelines regarding evictions or development-induced displacement must be reviewed, adequate notices must be given to those to be affected, and adequate compensation and rehabilitation must be provided in cases that merit such within the law (national and international). Above all, any planned evictions must satisfy all laws, both locally, nationally, and globally.

Based on the study carried out, the following actionable recommendations have been proffered in order to forestall further impoverishment by the practice of forced evictions and development-induced displacement. These suggestions are in line with best practices in the fields of urban and regional planning. It is vital to find a sustainable solution to this problem since it is a vicious cycle. Eviction only creates more slums. The notion that if the residents of slum areas are evicted, they go away, does not always work out, as can be seen from the survey. Many still stay around, especially since they have not been appropriately relocated. Actionable recommendations to mitigate future occurrences are hereby proffered.

First and foremost, there should be more effort on the part of the Government to provide affordable housing for the urban poor. This effectively nips the problem of slum proliferation in the bud. When the urban poor and city migrants have access to affordable housing, it is expected that slum occurrences would be effectively reduced. This necessitates active Government involvement in mass housing schemes, which are modest in price. Viable alternatives to forced eviction should be considered. These include the formalization or regularization of the tenure or dwellers of informal settlements, upgrading and rehabilitation schemes. These are more sustainable and are more productive than indiscriminately displacing people. The decision-makers, in this context, the Government, should introduce comprehensive, practical, and coherent laws and policies to prevent and sanction forced evictions, especially of the urban poor. This means they should also let the law to take its course and not interfere with the due process of enforcing such laws as they are not above the law. Existing laws such as the Nigerian Urban and Regional Planning Law of 1992 should also be reviewed in line with current International laws on forced evictions.

The Government should also clarify the precise conditions and procedures under which evictions of settlers occupying public and private land in urban areas can be carried out and ensure the legality and necessity of such evictions. The Government should provide and ensure jurisdictional and procedural clarity concerning the government authority responsible for issuing eviction notices. This authority can then be sanctioned for negligence or improper dispensation of its duties. The Government and its agencies must, therefore, ensure effective prosecution of individuals and institutions of authority initiating and conducting unlawful evictions. Governmental authorities responsible should always provide adequate and reasonable notice to those at risk of eviction in a standardized written format, as well as within the stipulated period. Genuine consultation with the threatened community is also mandatory. Authorities should also ensure that the use of excessive force during evictions, including unlawful and unnecessary detention, ought to be discouraged.

In line with best practices, adequate government-assisted relocation/re-housing options with sufficient infrastructure and public utilities must be provided for the evictees. There should be methods to assess losses incurred as a result of evictions, taking into account the individual's tenure status. This method should be documented and be in line with international standards, and a compensation plan should be 
drawn from this. All of these should be done before the evictions and not after. Urban planners must take into account the specific needs of the poorest while preparing relevant urban land and housing plans and policies.

Affordable housing for low-income earners, even within mega-cities such as Lagos State, remain a feasible and viable option towards reducing the proliferation of slums and informal settlements. This study also recommends the need for embracing temporary mobile housing with the use of cheap and affordable materials as a room through which all city dwellers can be integrated into the city space and sustainability can also be achieved. It is imperative to note that these temporary housing options can also be used as homes to temporarily house potential evictees before complete resettling is put into place.

\section{References}

Adekola, P., Allen, A., \& Tinuola, F. (2017). Socio-economic and Health Implications of Urban Renewal on Internally Displaced Persons in Ogun State, southwestern Nigeria, Journal of Internal Displacement, 7(1), 16-30.

Agbaje, E. (2013). Modernisation, urban renewal and the social cost of development. Mediterranean Journal of Social Sciences 4 (10), 318-324.

Agbola, T., \& Jinadu, M (1997). Forced Eviction and Forced Relocation in Nigeria: The Experience of those Evicted from Maroko, Lagos. Environment and Urbanisation, 2(23), 271 $-287$.

Ajanlekoko, J.S. (2001). Sustainable Housing Development in Nigeria - the Financial and Infrastructural Implication. Paper presented at the International Conference on Spatial Information for Sustainable Development, Nairobi, Kenya. 2 - 5 October.

Alagbe, O.A. (2006). Combating the challenges of rise in Urban slums in cities in developing World: A case study of Lagos State. Paper presented at the International Conference organised by the Department of Architecture, College of Science and Technology, Covenant university, Ota, Ogun State on 24 to 26 January, 2006 on The Built Environment Innovation Policy \& sustainable at Covenant University lecture Theatre, Covenant university, Ota, Ogun State

Amakihe, E. (2017). Forced eviction and demolition of slum: A case study of the Makoko slum in Lagos, Nigeria. Journal of Urban Regeneration \& Renewal, 10(4), 400-408.

Amnesty International (2006), Nigeria: Forced evictions in Lagos make thousands homeless United Kingdom: Peter Benenson House.

Amnesty International (2013). If you love your life, move out! Forced Eviction in Badia East, Lagos state, Nigeria. United Kingdom: Peter Benenson House.

Badiora, A. (2017). Civil Unrest, Insurgences and the Challenges of Community Displacement in Sub-Saharan Africa: A Silhouette of selected states in Nigeria, International Journal of Criminal Justice Sciences, 12(2), 302-318

Campbell, J (2012). This is Africa's New Biggest City: Lagos Nigeria, Population 21 Million". Available at: http:// www.theatlantic.com/international/archive/2012/07 [Accessed June 8, 2018]

Clarke, A., Hamilton, C., Jones, M., \& Muir, K. (2017). Poverty, evictions and forced moves.

Joseph Rowntree Foundation and University of Cambridge. ISBN 9781910783979

Commission on Human Security (2003). Human Security Now: Final Report, New York: CHS.
Center on Housing Rights and Evictions (COHRE) (2003). Forced Evictions: Violations of Human Rights No. 9. Geneva: COHRE

COHRE (2009). Forced Evictions: Violations of Human Rights No. 11 Geneva: COHRE

Cernea, M. (1995). Social Integration and Population Displacement, International Social Science Journal, 143/1.

CityMayors (2014). The World's Fastest Growing Cities and Urban Areas From 2006-2020. Available at: http:// www.citymayors.com/statistics/urban_growth.html [Accessed 20th October 2017].

Desmond, M., \& Shollenberger, T. (2015). Forced displacement from rental housing:

Prevalence and neighborhood consequences. Demography, 52(5), 1751-1772.

Desmond, M and Gershenson, C (2017). Who gets evicted? Assessing individual, neighborhood, and network factors, Social Science Research, 62, 362-377.

Didymus, J. (2012) Nigeria: Lagos authorities demolish homes in Makoko floating slum Available at: http:// www.digitaljournal.com/article/329529\#ixzz5TzLEzzg4 [Accessed 15 October 2018]

Dobson, S. (2017). Community-driven pathways for implementation of global urban resilience goals in Africa, International Journal of Disaster Risk Reduction, 26, 78-84.

Du Plessis, J. (2005).The growing problem of forced evictions and the crucial importance of community based, locally appropriate alternatives, Environment and Urbanization, 17(1), 123-134.

Filani, M. O. (2012). The changing face of Lagos: From vision to reform and transformation. Report funded by Foundation for Development and Environmental Initiatives (Nigeria), and Cities Alliance.

Fox, S. (2014). The Political Economy of Slums: Theory and Evidence from Sub-Saharan Africa, World Development, 54,191-203

Gandy, M. (2005). Learning from Lagos. New Left Review, 33, 37.

Habitat International Coalition (HIC) (2018). Nigeria: Forced evictions in Lagos make thousands homeless. Available at: http://www.hic-gs.org/topdf.php?type=A\&pid=1908 [Accessed 2 October 2018]

Hossain, S. (2013). Migration, urbanization and poverty in Dhaka, Bangladesh. Journal of the Asiatic Society of Bangladesh (Hum.), 58(2), 369-382.

Islam, M. R., \& wa Mungai, N. (2016). Forced eviction in Bangladesh: A human rights issue. International Social Work, 59 (4), 494-507.

Keating, W. (2018). Evicted: Poverty and profit in the American city, by Matthew Desmond, Journal of Urban Affair, 40(1), $152-154$

Lancione, M (2017). Revitalising the uncanny: Challenging inertia in the struggle against forced evictions, Environment and Planning D: Society and Space, 35(6), 1012 - 1032

Marshall, M. N. (1996). Sampling for qualitative research. Family practice, 13(6), 522-526.

Marcus, J and Zuk, M. (2017). Displacement in San Mateo County, California: Consequences for Housing, Neighborhoods, Quality of Life, and Health, Institute of Governmental Studies Research Brief, 1-15. Available at: https:// escholarship.org/uc/item/0n904028 [Accessed 2 October, 2018]

Morka, F. (2007). A place to live: a case study of the Ijora-Badia community in Lagos, Nigeria: Case study prepared for Enhancing Urban Safety and Security: Global Report on Human Settlement Available from http://www.unhabitat.org/ grhs/2007 [Accessed 6 August, 2014]

Munoz, S. (2018). Urban Precarity and Home: There Is No "Right to the City, Annals of the American Association of Geography, 108(2), 370-379

National Bureau of Statistics (2010), Annual Abstract of Statistics, 
2010. Federal Republic of Nigeria. Available from http:// www.nigerianstat.gov.ng. Retrieved on 27 October, 2017

Nigerian Urban and Regional Planning Decree (88) of 1992, CAP N138 LFN 2004. The Federal Government: Lagos.

Numbeo (2015). Cost of Living in Lagos, Nigeria. Available at: http://www.numbeo.com/costofliving/city_result.jsp? country=Nigeria\&city $=$ Lagos [Accessed 3 March 6, 2018].

Nwanna, C. R. (2012). Gentrification in Lagos state: Challenges and prospects. British Journal of Arts and Social Sciences, 5(2), 163-176.

Nwobueze, C. C., Okolie-Osemene, J., \& Young, N. J. (2018). The State, Urban Displacement

and Land Rights in Nigeria. Advances in Social Sciences Research Journal, 5(8) 80-91.

Ocheje, P. (2007). "In the Public Interest": Forced Evictions, Land Rights and Human Development in Africa, Journal of African Law, 51(2), 175-214

Ogunlesi, T. (2016). Available at: https://www.theguardian.com/ cities/2016/feb/23/makoko-lagos-danger-ingenuity-floating -slum [Accessed 15 October 2018]

Paller, J. W. (2017). The Contentious Politics of African Urbanization. Current History, 116 (790), 163-169.

Popoola, A., Tawose, O., Abatan, S., Adeleye, B., Jiyah, F., \& Majolagbe, N. (2015). Housing

Conditions and Health of Residents in Ibadan North Local Government Area, Ibadan, Oyo State, Nigeria. Journal of Environmental Sciences and Resource Management, 7(2), 59-80.

Small, M.L. (2009). How many cases do I need? On science and the logic of case selection in field-based research. Ethnography $10,5-38$.

Srinivas, H. (2004). "Defining Squatter Settlements". An Urban Environmental Management Website paper publication under the theme "Urban Squatters and Slums". http:// www.gdrc.org/ucm/squatters/define-squatter.html retrieved on 12 August, 2016, 1:15pm.
Sullivan, E. (2017). Displaced in Place: Manufactured Housing, Mass Eviction, and the Paradox of State Intervention, American Sociological Review, 82(2), 243-269

UNCHS (Habitat) (1993). National Trends in Housing Production Practices Volume 4: Nigeria. HS/313/93 E, Nairobi.

United Nations Development Programme (UNDP) (1994). Human Development Report 1994 - New Dimensions of Human Security. New York: Oxford University Press.

UN-Habitat (2003). The Challenges of Slums. UN-Habitat new Global Report on Human Settlement. London: Earthscan.

UN-Habitat (2007). Forced Evictions- Toward Solutions? Second Report of the Advisory Group on Forced Evictions to the Executive Director of UN-Habitat.

UN-Habitat (2008). State of the world's cities 2010/2011: Bridging the urban divide. Earthscan Publications Ltd: London

United Nations Human Settlement Programme (UN-HABITAT) (2011). Forced Evictions: Global Crisis, Global Solution. Nairobi: UN-HABITAT

United Nations Human Rights Office of the High Commissioner (2014), Forced Evictions Fact Sheet No. 25/Rev.1. Kenya: UNHRC

Urban Poor Associates. (17 December 2006). The daily urban poor. Available at:

http://urbanpoorassociates.blogspot.com/2006/12/ [Accessed 15 October 2018]

World Bank (2006). Nigeria - Lagos Metropolitan Development and Governance Project: Project Appraisal Document, p.2. Nigeria: World Bank

Yamane, T (1967). Statistics: An Introductory Analysis, $2^{\text {nd }}$ Ed., New York: Harper and Row. 